\title{
An Analysis Of The Potency And Opportunities For The Youth Participation In The Development Of Wiyono Village District Pesawaran Lampung
}

\author{
Banon Eko Susetyo \\ Sekolah Tinggi Keguruan dan Ilmu Pendidikan Tunas Palapa \\ banon.perkuliahan@gmail.com \\ Juni Bayu Saputra \\ Sekolah Tinggi Keguruan dan Ilmu Pendidikan Tunas Palapa \\ junibayu.albana@gmail.com
}

\begin{abstract}
This research is an exploratory study that wants to study the role of youth in village development in Wiyono Village, Gedong Tataan District, Pesawaran Regency. The research is based on the background of the fact that Wiyono Village is a City Village that has many facilities with relatively advanced population, but is still a developing village, not a fast developing village. This is interesting to study to find out what causes it. The research population was all village youths with 32 people drawn from eight hamlets in Wiyono Village. The study was conducted with an exploratory approach using qualitative descriptive methods. The results showed that the potential of Wiyono Village youth was in the high category with a score of 4, while the level of youth participation in village development was in a moderate position with a score of 3. The main cause of the lack of optimal youth participation was the lack of communication between the village government and the youth.
\end{abstract}

\section{Key Words: Potential Analysis, Youth Participation, Village Development}

\section{INTRODUCTION}

Youth is dubbed the pillar of the state. This is evidenced by the fact that throughout the history of the nation's struggle, youth involvement has always been seen, even youth is a prime mover and principal in the struggle of the nation. Law Number 40 of 2009 concerning Youth states that youth play an active role as a moral force, social control, and agent of change in all aspects of national development. However, there are still groups of youth who have not shown their active role. The phenomenon of youth movements that have existed still does not represent the participation of all or at least the majority of youth at all levels of society. In the regions, including in the villages there are still not many young people involved in development. Therefore, efforts are needed to empower youth to the village / kelurahan level.

Wiyono Village, Gedong Tataan Subdistrict, Pesawaran Regency is a village based on the Regent's decree by referring to the Minister of Home Affairs Regulation 


\section{4 | Banon, Juni BS. An Analysis Of The Potency...}

No. 81 of 2015 concerning Evaluation of Village and Village Development, which is still included in the Developing Village category, not yet included in the Rapid Developing Village category. In fact, if seen from the location in the district city area, the potential of the village, the condition of the community, and youth activities, then it should be able to become a Rapidly Developing Village. This situation is quite interesting to observe.

One of the factors that deserves to be examined in relation to the progress of development in Wiyono Village, Gedong Tataan Subdistrict, Pesawaran District, is the participation of young people. The basic assumption used is that youth participation is very influential in accelerating village development, but this participation can be constrained by the low insight of youth, by the low potential of youth, and by the lack of openness of village government.

The aim of this research is to empirically examine the condition of the youth of Wiyono Village, Gedong Tataan Subdistrict, Pesawaran Regency, including:

1. Potential owned by Wiyono Village youth, which includes;

2. Understanding of the rights and obligations of youth in village development;

3. Openness of village government to opportunities for youth participation;

4. The possibility of a link between youth participation and the potential possessed by youth, understanding of youth rights and obligations in village development, and openness of village governance to opportunities for youth participation;

5. This research is expected to provide benefits as a reference for policy making at the village, sub-district and district levels and be a material for evaluating youth development, both at the regional and central levels.

\section{THEORITICAL REVIEW}

The role of youth in the journey of village development becomes crucial, where the starting point for change begins with the youth struggle. One way to increase youth participation in the community is to involve youth in activities in the neighborhood or in the village. Thus providing opportunities for youth to play an active role in the development of this nation. This is what is meant by youth participation.

Suryana (2010) defines participation as a process of community involvement at all stages of the development process in the community itself. Youth as one part of the community certainly has its own task and form of participation, especially in rural community development. ${ }^{1}$

The emergence of youth participation in village development is not only determined by youth initiatives, but can be derived from efforts to involve the village government. Article 4 letter d of Law Number 6 Year 2014 concerning Villages states that village arrangements aim to encourage initiatives, movements and participation of village communities for the development of potentials and Village Assets for mutual prosperity. ${ }^{2}$ Thus building village community participation is a mandatory task for village governments. Adisasmita (2006) states that the village government apparatus as a leader as well as the organizer of development in the village has a responsibility for the changes that will occur, both changes that occur in the

\footnotetext{
${ }^{1}$ Suryana (2010).

${ }^{2}$ Undang-undang Nomor 6 Tahun 2014 about Village
} 
community and social social changes. For this reason, the village government as the head of government in anticipating these changes must have the ability to think or act rationally in making decisions that will occur in the midst of the community. ${ }^{3}$

Mondong (2011) states, the village government has an important role for the progress and development of the village. The village government has a function in terms of fostering the community in all fields. The village government also has the task of carrying out community services. In terms of the task of fostering the community, the village government has the responsibility to motivate and facilitate the community in achieving prosperity. ${ }^{4}$ Whereas in the case of community service tasks, the task of the village government is to provide government administrative services in the framework of orderly governance.

If the village government has carried out its function as a development facilitator, then the next demand is the emergence of community awareness to participate in development in his village. Participation that should be realized by the community (including youth) in rural development according to Erickson in Slamet, (1994) is divided into three stages, namely: ${ }^{5}$

\section{Idea planning stage}

Participation at this stage means the involvement of a person in the preparation of plans and strategies in the preparation of the committee and budget in an activity / project. The community participates by giving suggestions, suggestions and criticism through meetings that are held.

\section{Participation in the implementation stage}

Participation in this stage means the involvement of a person at the implementation stage of a project. The community here can provide energy, money or material / goods as well as ideas as one form of participation in the work.

\section{Utilitation stage}

Participation at this stage means the involvement of a person in the stages of the utilization of a project, after the project is completed. Community participation at this stage in the form of energy and money to operate and maintain the project that has been built.

The three types of community participation in rural areas must be realized by the government in the village, so that rural development targets can be quickly achieved. In fact, Davis (1990) stipulates that there are four domains of participation, namely the planning phase, the implementation phase, the utilization phase, and the evaluation phase. The stages of community participation in village development can be described as follows:

\footnotetext{
${ }^{3}$ Adisasmita, Rahardjo., 2006. Membangun Desa Partisipatif, Yogyakarta: Graha Ilmu Graha Ilmu

${ }^{4}$ Mondong, Hendra. 2011. Peran Pemerintah Desa Dalam Meningkatkan Partisipasi Masyarakat Dalam Pembangunan Desa. Medan: USU
}

${ }^{5}$ Slamet, Y. 2003. Pembangunan Masyarakat Berwawasan Partisipasi, Surakarta: Sebelas Maret University Press 
1. Development Planning: planning is the beginning of the process of participation involved in determining what programs will be built. Planning in the broadest sense is a process of systematically preparing for activities to be carried out to achieve a certain goal;

2. Implementation of Development; development implementation stage is the implementation of programs that have been approved or decided in the decision making stage. Implementation means community involvement in the implementation. This implementation phase can take the form of physical participation such as the provision of energy or the giving of donations and materials for development;

3. Utilization of Development Results; the stage of yield utilization is the stage where the community gets the results of the development program that has been implemented. The acceptance of these results is a manifestation of participation. Utilization is the most important element in development, because if the results of the development are not utilized properly, the implementation of development cannot be enjoyed in the long term;

4. Evaluation of Development Success; evaluation is very important for every development implementation, which is the process of evaluating the achievement of objectives and disclosure of program / activity performance problems to provide feedback on the quality of program / activity performance

\section{The Condition of Wiyono Village}

Wiyono Village is located in the District of Gedong Tataan District, Pesawaran Regency, Lampung Province. With an area of 1,100 hectares, or $6.66 \%$, the width of the Gedong Tataan sub-district, this village is a medium-sized village. The largest village in Gedong Tataan Subdistrict is Taman Sari Village with an area of 2,094 hectares or $12.68 \%$, while the smallest village is Padang Ratu Village with an area of 280 hectares or $1.69 \%$ of the area of Gedong Tataan Subdistrict.

Almost all of Wiyono Village's land is dry land in the form of a yard with an area of 1,050 hectares, while the paddy field is only 50 hectares. This village is located at an altitude of 180.3 meters above sea level. The distance of the village to the subdistrict center is $3.5 \mathrm{~km}$, to the district head office is $7.2 \mathrm{~km}$, and to the provincial government center is $22.50 \mathrm{~km}$. Wiyono village has eight hamlets, with a total of 15 village officials consisting of a village head, a village secretary, five heads of affairs, and eight hamlet heads.

In terms of economic status, Wiyono Village is a self-sufficient village, but based on the status of development progress, this village is still considered a developing village, not a Rapid Developing village. This condition is quite ironic, considering that Wiyono Village is the closest village to the city center (Gedong Tataan). Based on the location of the area, this village is also on the main road connecting the regencies and provinces.

The progress of the village can be seen from the fact that of 1,823 existing houses, none of them have yet to use PLN electricity. When viewed from the state of the house, 1,418 permanent houses were recorded, 243 were semi-permanent, and 162 were not permanent. The village has a village market, is located across the inter-provincial route, and there are modern shops, has one kindergarten, 4 elementary schools, one supporting peskesmas, one pharmacy, one clinic, 8 posyandu, one doctor, five midwives, and five caring. The village has eight mosques, 
14 mushallas, four Christian churches and one Catholic church. This condition indicates that Wiyono Village is an advanced village.

In terms of government conditions, Wiyono Village is a village with a distinct village status in the category of self-sufficiency. This village consists of eight hamlets with 30 RT. The village administration consists of one village head, one village secretary, five affairs heads, and eight hamlet heads. The administration of the government is in accordance with the provisions of the administration of the village government, in the sense that the process of community service runs normally, the hours of service are sufficiently obeyed, the presence of village government officials according to the rules.

Wiyono Village residents in 2018 recorded 7,718 people consisting of 3,975 men and 3,742 women. The population density in this village is 701.64 inhabitants / $\mathrm{km} 2$. Statistical data states, the population aged $17-40$ years totaling 2,214 people with the highest level of education in high school, most of the activities outside the village daily.

Wiyono Village Youth is included in the active category, with the types of learning activities (school / college) and work (employees, entrepreneurs, and entrepreneurs), and most of them are casual workers. Not many unemployed youths in Wiyono Village, if interpreted that unemployment is people do not have a source of income. However, if unemployment is defined as a person who does not have a permanent job, then the condition of Wiyono Village is still quite a lot of unemployment. This happened because quite a lot of people in Wiyono Village were looking for income at odd jobs.

The youth organizations in the village are Karang Karuna Desa and the Mosque Youth Association (IRMAS). Youth organizations only exist in villages, with members of village youth who are active and like to organize. At the time of the research, the condition of the youth group was inactive. The Karang Karang cadet village of Wiyono is only active when there are certain events, for example there are commemorative holidays, there are invitations to participate in competitions, and village cleanliness.

Mosque youth association (IRMAS) exists in eight mosques. This Islamic youth organization also did not appear to have any activity at the time the research was conducted. IRMAS activities will occur if the commemoration of Islamic holidays, or national holidays. In this momentum, the IRMAS board held a number of Islamic nuances, such as the Qur'an reading competition and the Qasidah competition.

The involvement of youth in the activities of political organizations and mass organizations is very small. The observation found that there were no 20 percent active youth in the organization. At the time the Karang Taruna organization was being researched there was no activity, while IRMAS was seen as having activities ahead of the religious holidays.

\section{RESEARCH METHOD}

The study was conducted using an exploratory approach with qualitative descriptive methods. Data was collected using observation techniques, questionnaires, and interviews with the sampling method. The number of samples taken was 32 youths from eight hamlets in Wiyono Village. The Research was started from April $1^{\text {st }}$ to November $31^{\text {st }}$ 2019. The basic assumption of this research is that youth participation in village development will be influenced by the level of youth potential, 
understanding of youth rights and obligations in village development, and openness of village governance to opportunities for youth participation.

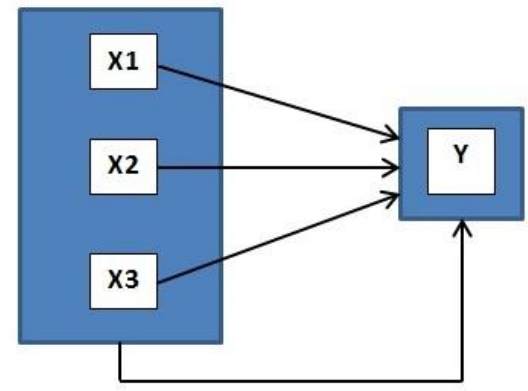

Figure 1: Constellation of Research Problems

Information:

$\mathrm{Y}=$ Youth participation in village development

$\mathrm{X} 1$ = Youth potential

$\mathrm{X} 2=$ Understanding of the rights and obligations of village development

$\mathrm{X} 2$ = Openness of the village government to youth participation

Data analysis was performed by interpreting the results of the data collection through observation, interviews, and the distribution of questionnaires then scoring 1-5 on a scale with guidelines:

1) Score of 5 categories is very good

2) Score of 4 categories is good

3) Score 3 medium categories

4) Score of 2 categories are not good

5) Score of 1 category is not good / bad

\section{RESULTS AND DISCUSSIONS}

Youth Participation at Wiyono Village

Analysis of the youth participation rate of Wiyono Village, Gedong Tataan Sub-district, Pesawaran District, was conducted by examining the youth potential and opportunities provided by pemua, and the real conditions of the youth participation rate of Wiyono Village.

Analysis of youth potential is seen based on the level of education and knowledge of government, health conditions (physical and mental), understanding of the village development process, and understanding / awareness of the rights and obligations to participate in village development. Based on the results of research through exploratory approach with qualitative descriptive methods by using observation, interviews, and questionnaires obtained data that the average level of potential youth in the Village Wiyono included in the good category. Based on the level of education, from 32 respondents, youth with tertiary education (score 5) 
there are 6 youth, high school (score 4 ) there are 14 youth, SMTP (score 3 ) there are 9 youth, elementary (score 2) there are 3 youth, and no some did not graduate from elementary school. Based on the level of health of the respondents obtained data that youth who are physically and mentally healthy with a score of 5 as many as 30 youth, while 2 people have a score of 3 (psychologically unhealthy physically). Based on the understanding of rights and obligations, the number of youths with a score of 5 (understanding and active) is 2 people, score 4 (know, carry out, less active) as many as 10 people, score 3 (know, carry out if governed) as many as 19 people, score 2 (know but don't implement) no, and score 1 (don't know and don't implement) 1 person. Based on youth understanding of the development process, data on the number of youth with a score of 5 (4 aspects) is 2 people, score 4 (knows 3 aspects) as many as 19 people, score 3 (knows 2 aspects) 10 people, Score 2 (knows 1 aspect) 1 people, and score 1 (don't know) no.

The results of the calculation of the average youth potential of Wiyono Village are 3.96 , which means it is categorized as good. 
Table 1: Youth Potency

\begin{tabular}{|c|c|c|c|c|}
\hline No & Variabel / Indikator & Jumlah & Skor & Total Nilai \\
\hline \multicolumn{5}{|c|}{ A. Level of Education } \\
\hline \multicolumn{5}{|c|}{ How high the level of youth education is? } \\
\hline & 1. Not graduated from elementary school & 0 & 1 & 0 \\
\hline & 2. Elementary & 3 & 2 & 6 \\
\hline & 3. Junior high school & 9 & 3 & 27 \\
\hline & 4. High school & 14 & 4 & 56 \\
\hline & 5. College & 6 & 5 & 30 \\
\hline \multicolumn{4}{|c|}{ Average score of A } & 3,72 \\
\hline \multicolumn{5}{|c|}{ B. The level of health } \\
\hline \multicolumn{5}{|c|}{ To what extent are the physical and mentally health of youth? } \\
\hline & 1. Poor physical and psychological health & 0 & 1 & 0 \\
\hline & 2. Physical health, psychological health & $\mathbf{0}$ & 2 & 0 \\
\hline & 3. Psychic health, less physical health & 2 & 3 & 6 \\
\hline & 4. Physical and psychological health, there are limitations & 0 & 4 & $\mathbf{0}$ \\
\hline & 5. Physical and psychological health, without limitations & 30 & 5 & 150 \\
\hline \multicolumn{4}{|c|}{ Average score of B } & 4,88 \\
\hline \multicolumn{5}{|c|}{ c. Understanding of rights and obligations in village development } \\
\hline \multicolumn{5}{|c|}{ To what extent are youth's understanding of obligation rights in village development? } \\
\hline & 1. No / less insight & 1 & 1 & 1 \\
\hline & 2. Know but not implement & 0 & 2 & 0 \\
\hline & 3. Know, carry out if ordered & 19 & 3 & 57 \\
\hline & 4. Know, implement, not active & 10 & 4 & 40 \\
\hline & 5. Know and be active & 2 & 5 & 10 \\
\hline \multicolumn{4}{|c|}{ Average score of $\mathrm{C}$} & 3,38 \\
\hline \multicolumn{5}{|c|}{ D. Insights into the village development process } \\
\hline \multicolumn{5}{|c|}{ What is the understanding of the planning, implementation, utilization, evaluation processes? } \\
\hline & 1. Do not know & 0 & 1 & $\mathbf{0}$ \\
\hline & 2. Know one aspect & 1 & 2 & 2 \\
\hline & 3. Know two aspect & 10 & 3 & 30 \\
\hline & 4. Know three aspect & 19 & 4 & 76 \\
\hline & 5. Know four aspect & 2 & 5 & 10 \\
\hline & \multicolumn{3}{|l|}{ Average score of D } & 3,69 \\
\hline & \multicolumn{3}{|l|}{ Total average score } & 3,91 \\
\hline
\end{tabular}

The results of data collection through questionnaires, interviews, and observations about the real conditions of youth involvement in development resulted in an average score of 2.60 , which means that it is categorized as below medium or not good.

On the score of youth involvement in public activities a score of 2.38 is obtained. In this case, many young people are involved, but not as initiators and managers, but merely participate in activities.

On youth involvement in development planning a score of 1.75 was obtained. This means a bad number. In Wiyono Village, young people are indeed less involved in development planning. The process of proposals from youth is unknown to youth. As many as 21 respondents said they never knew and were never involved.

In the involvement of youth in the implementation of development obtained a score of 2, which means it is not good. 19 respondents said that in the implementation of 
development, youth were not involved by the village government, 6 respondents said that only youth were selected, and 5 respondents said the village government involved youth representatives.

In the involvement of youth in the use of scores obtained high enough, which is 3.13 which means it is included in the medium category. As many as 16 respondents said that only selected youth activists were involved as managers or workers on village development objects, for example in village business units.

In the youth involvement in the evaluation of village development, a score of 3.19 was obtained, which meant it was in the medium category. In this case 10 respondents mentioned that the village opened itself to be openly corrected by youth. However, 6 respondents said that the evaluation was carried out in a special meeting involving only selected youth, and 5 respondents said that the only youth representatives included in the evaluation meeting were included, and 8 respondents claimed they had never involved youth in evaluating development.

The results of data collection on the availability of the budget to be managed by young people obtained a score of 2.53 which means it was categorized as not good. A total of 10 respondents said there was a budget allocation that could be managed by youth but the allocation was not realized, in fact 8 respondents said there was no allocation of funds whose implementation involved youth.

The results of data collection on the use of youth centers produce a score of 3.25 which means it is medium categories. As many as 12 respondents said that in Wiyono Village the village did not use youth facilities to involve youth in development, 6 respondents said the village rarely uses youth containers, 4 respondents said the village used a youth forum selected, and 9 respondents said the village always involved youth organizations.

Table 2: Youth Opportunities 
222 | Banon, Juni BS. An Analysis Of The Potency...

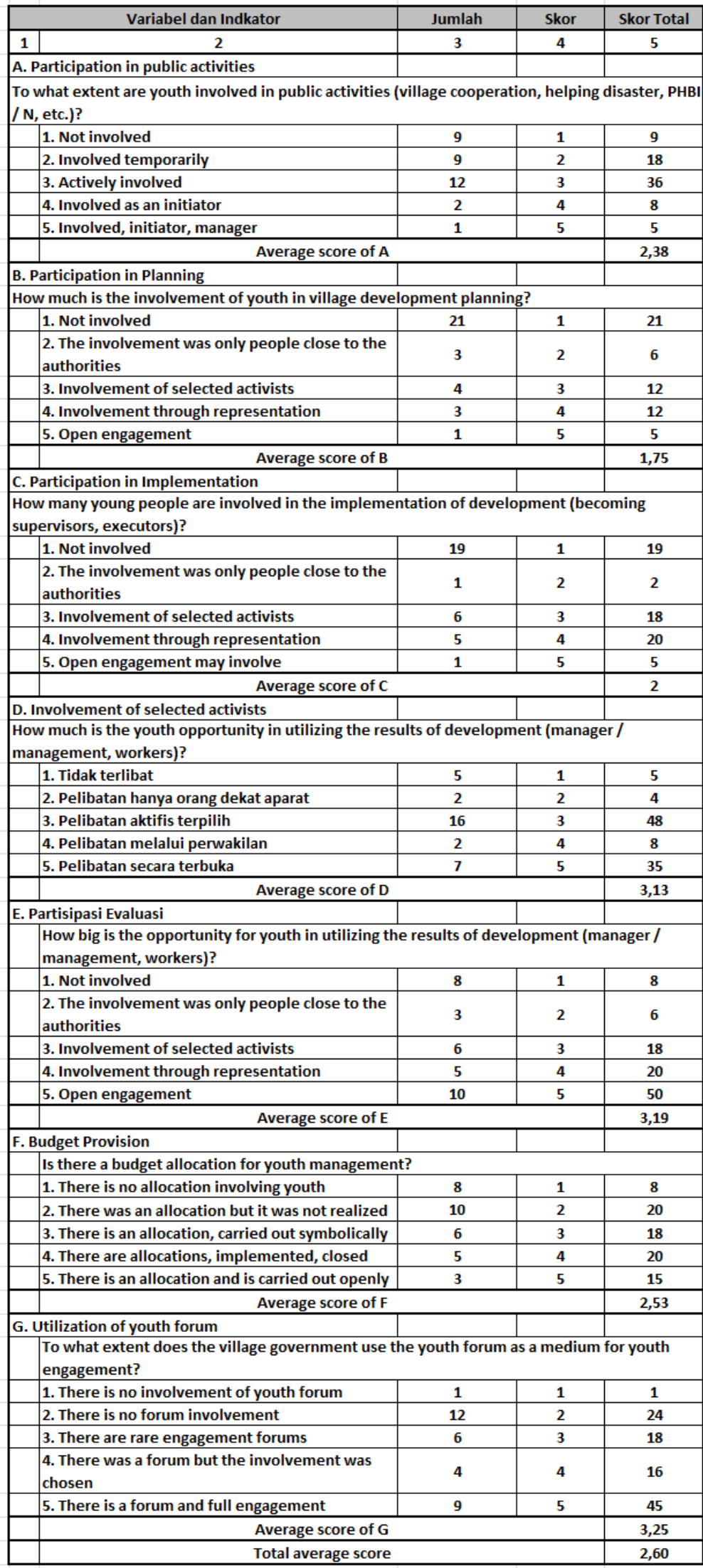


The search results in Wiyono Village show that youth forums in the form of youth clubs, Risma, and special forums created by villages have never been used to involve youth in development throughout the process, both planning, implementation, use, and evaluation. The involvement of youth in development is only in the process of implementation, and even then in the form of village or hamlet community service activities. In addition, the Wiyono village government showed less openness to the community. Accountability for the use of village funds is not publicly publicized by the village government, as do several villages in Pesawaran District. A number of young people claimed that they could never know how much the village budget was, and what programs the village would fund.

A more in-depth search of the reasons for the exclusion of youth obtained data that the village government did not involve many youths because more young people did not want to be involved in the entire village development process on the grounds that they did not have time. The number of activities outside the village so that going home into the night is the cause of the lack of youth involvement in the entire development process.

From the results of the analysis of the participation of the youth of Wiyono Village, it shows that the participation of the youth of Wiyono Village is still low. That was caused by two things. First, the youth's busy schedule (studying and working outside the region) has caused a lack of time for youth to participate in the village. Second, the lack of opportunities for young people to participate in village development. This lack of openness is due to the fact that youths have not shown initiative in participating. In other words, the cause of the lack of youth participation in Wiyono Village is the lack of communication between the village government and all youth in the village. owever, it is also possible because among the village youth there are no young leaders who have leadership and creativity to arouse the youth's passion to build the village. Youth seem to be passive towards the progress of the village, so there is no youth initiative to develop the village yet. For example, at the time of this research it was discovered the potential for the development of water dam tourism objects, but the initiative to develop these attractions was precisely from parents (community leaders), not from youth. Whereas, it is hoped that young people will respond to the potential first and then submit proposals to the village to be funded.

On the other hand, the village government does not appear to be actively exploiting the potential of youth. Existing youth organizations, in the form of Youth Organization and RISMA have not been utilized optimally to build youth involvement in village development. Village meetings have not included youth to participate in it. Preparation of development plans, implementation of development, and evaluation of development outcomes do not involve youth, both organizationally and personally.

Guidance on Wiyono Village youth is not visible. That is caused by the lack of creative youth figures and figures who have the soul of a leader and have high creativity. Karang Taruna Chairperson who was supposed to be the motor of youth mobilization had other activities which caused a lack of time to arouse youth motivation. Meanwhile, creative community figures also do not exist in Wiyono Village. That resulted in the low participation of youth in development. 


\section{CONCLUSION}

The Development of Wiyono Village, Gedong Tataan Subdistrict, Pesawaran Regency, faced the problem of the lack of youth participation in village development. The obstacle is that the potential of youth has not been utilized and the role of village government is not yet optimal.

Wiyono Village Youth has good potential to develop the village, but with the lack of guidance and support from the village administration, the potential cannot develop. Busyness in personal activities is the dominant reason for youth not to participate much in village development. Meanwhile, the village government has not optimized its role to foster youth. The village administration has not utilized youth forums (Karang Taruna and RISMA) to become a vehicle for youth development, so that communication between the village government and the village youths is constrained.

With the conditions in Wiyono Village, it requires the involvement of a third party from outside Wiyono Village, in this case it takes a partnership between the village government and universities, NGOs, and other institutions (interest groups concerned with village development). The existence of these third parties is important to guide and drive village youth activities, so that a culture of youth participation can be formed in Wiyono Village.

\section{SUGGESTION}

Efforts to foster youth are needed through strengthening youth understanding of the village development process. The village government needs to motivate youth to activate youth organizations so that they appear ready to develop the village. The publication of village budgets needs to be done by installing large enough announcements so that the community knows how and how to use village budgets.

\section{REFERENCES}

Adi, I.R. 2001. Pemberdayaan, Pengembangan Masyarakat, Intervensi Komunitas (Pengantar pada pemikiran dan Pendekatan Praktis). Jakarta : Fakultas Ekonomi Univeritas Indonesia.

Adisasmita, Rahardjo., 2006. Membangun Desa Partisipatif, Yogyakarta: Graha Ilmu Graha IImu.

Astuti. Siti Irene, 2011 Rural Development Participation: Concepts and Measures for Project Design, Implementation and Evaluation. Ithaka: Cornel University.

Barry, Monica. 2005. Youth Policy and Social Inclusion, Critical debate with Young People, London: Routlegde.

Corsaro, William. A. 1997. Teh Sociology of Childhood. California: Pine Forge Press

Davis. 1990. Partisipasi Masyarakat Desa Dalam Pembangunan. Semarang: Gramedi. 
Banon, Juni BS. An Analysis Of The Potency... | 225

Deviyanti, D. 2013. Studi tentang Partisipasi Masyarakat dalam Pembangunan di kelurahan Karang Jati Kecamatan Balikpapan Tengah. E-Journal Administrasi Negara 20131 (2). Fisip Unmul.org

Hurlock, E.B.1980. Psikologi Perkembangan, Suatu Pendekatan Sepanjang Rentang Kehidupan. Jakarta : Erlangga.

Khairuddin. 2000. Pembangunan Masyarakat. Yogyakarta: Liberty.

Laksmono, Bambang Shergi. 2011. Pidato peluncuran Pusat Kajian Kepemudaan FISIP UI. Depok.

Marshall, Gordon. (1998). Oxford Dictionary of Sociology. New York: Oxford University Press.

Masdiana, E. dkk.2008. Peran Generasi Muda dalam Ketahanan Nasional. Jakarrta: Kementerian Pemuda dan Olah Raga Republik Indonseia;

Mondong, Hendra. 2011. Peran Pemerintah Desa Dalam Meningkatkan Partisipasi Masyarakat Dalam Pembangunan Desa. Medan: USU.

Rifko Setiawan Suangi, 2013. Peranan Pemerintah Desa Untuk Meningkat Partisipasi Masyarakat Dalam Pembangunan. Modayag Barat Manado.

Rita Eka Izzaty, dkk. 2008. Perkembangan Peserta Didik. Yogyakarta: UNY Press.

Rohmad, Z. 1998. Peran Pemuda dalam Pembangunan Masyarakat Pedesaan. Disertasi (Tidak diterbitkan). Bogor : Program Pascasarjana Institut Pertanian Bogor.

Sari, D.D. 2016. Peranan Karang Taruna dalam Meningkatkan Kepedulian Sosial Pemuda Kelurahan Margodadi Kecamatan Metro Selatan Kota Metro. Skripsi (tidak diterbitkan). Bandar Lampung: Fakultas Keguruan dan Ilmu Pendidikan Universitas Lampung.

Skelton, Tracey, Gill Valentine. 1998. Cold Places, Geography of Youth Cultures. New York: Routledge

Slamet, Y. 2003. Pembangunan Masyarakat Berwawasan Partisipasi, Surakarta: Sebelas Maret University Press.

Soetomo. 2008. Strategi-Strategi Pembangunan Masyarakat, Yogyakarta: Pustaka Pelajar.

Sudirman (tanpa tahun). Partisipasi Tokoh Masyarakat dalam Pembangunan Desa (Studi di Desa Unteboang Kecamatan Sosorgadong Kabupaten Tapanuli Tengah Provinsi Sumatera Utara). Medan: FIP UNIMED. 
226 | Banon, Juni BS. An Analysis Of The Potency...

\section{Peraturan Undang-Undang}

Undang-Undang Nomor 40 Tahun 2009 Tentang Kepemudaan

Undang-Undang Nomor 6 Tahun 2014 Tentang Desa

Undang-Undang Nomor 23 Tahun 2014 Tentang Pemerintahan Daerah. 